\title{
GGH wt Allele
}

National Cancer Institute

\section{Source}

National Cancer Institute. GGH wt Allele. NCI Thesaurus. Code C103944.

Human GGH wild-type allele is located in the vicinity of $8 \mathrm{q} 12.3$ and is approximately $24 \mathrm{~kb}$ in length. This allele, which encodes gamma-glutamyl hydrolase protein, plays a role in glutamine metabolism. 